\title{
ANALYSIS OF GROUNDWATER LEVEL VARIATIONS AND WATER BALANCE IN THE AREA OF THE SUDETY MOUNTAINS
}

\author{
Zofia RZEPECKA $^{1)}$ *, Monika BIRYLO ${ }^{1)}$, Joanna KUCZYNSKA-SIEHIEN ${ }^{1)}$, \\ Jolanta NASTULA ${ }^{2)}$ and Katarzyna PAJAK ${ }^{1)}$ \\ 1) University of Warmia and Mazury in Olsztyn, Oczapowski St. 1, 10-719 Olsztyn, Poland \\ ${ }^{2}$ Space Research Centre, Polish Academy of Sciences, Bartycka 18A, 00-716 Warsaw, Poland \\ *Corresponding author's e-mail: zofia.rzepecka@uwm.edu.pl
}

\begin{tabular}{l} 
ARTICLE INFO \\
\hline Article history: \\
Received 12 January 2017 \\
Accepted 4 May 2017 \\
Available online 29 May 2017 \\
\hline
\end{tabular}

Keywords:

Total water storage TWS

Water balance

Groundwater level

GRACE

GLDAS

\begin{abstract}
Water is one of the most important components of the environment, having a direct effect on the maintenance of life on the Earth. In this paper, analysis of groundwater level variations, water balance and all the parameters included in these quantities, i.e. precipitation, evapotranspiration, surface run-off and subsurface run-off, were performed in the area of the Sudety Mountains for the period of November 2002 - October 2015.

The groundwater level variations were computed on the basis of the mean Terrestrial Water Storage (TWS) values determined from Gravity Recovery and Climate Experiment (GRACE) observations and Global Land Data Assimilation System (GLDAS). TWS data have been determined with a spatial resolution of one degree and temporal resolution of one month. According to the results, groundwater level variation can be approximately determined by water balance changes (with reverse sign). Specifically, for the Sudety area a high average stability of total water storage over the period of past 13 years and decline in groundwater level by about $13 \mathrm{~cm}$ (approximately $1 \mathrm{~cm} /$ year) was detected.
\end{abstract}

\section{INTRODUCTION}

Earth's climate is changing, and it affects the global hydrologic cycle. Recent years have brought extreme droughts in some regions while in others flooding has been occurred more regularly and with greater intensity than before (Famiglietti and Rodell, 2013). Along with these variations, groundwater resources also can change. For example, in Poland a lowering of the groundwater level has been observed in last decade (Barlik et al., 2007; National Water Management, 2010). Such a situation can be particularly dangerous in regions with water deficiency, like e. g. in the Middle East (Voss et al., 2013), or at some regions of India or Africa (Chen et al., 2016; Scanlon et al., 2006). It should be recalled that the groundwater is an important source of clean water; for the whole Earth it covers approximately $50 \%$ of the drinking water needs, $40 \%$ of water consumption for industrial purposes and $20 \%$ of irrigation use (Zektser and Lorne, 2004).

In this paper, analyses of groundwater level (GWL) variations, water balance and related hydrological variables, i.e. precipitation, evapotranspiration, surface run-off and subsurface run-off, are performed in the Sudety Mountains for the period of November 2002 - October 2015. These parameters were analysed during this period, using a linear model which takes into consideration a bias, trend and seasonality. The second objective of the research was to compare the terrestrial water storage (TWS) obtained based on the Gravity Recovery and Climate Experiment (GRACE) observations and that derived from Global Land Data Assimilation System (GLDAS). TWS is the crucial element of the Earth terrestrial and global hydrological cycle; changes of TWS integrate the effects of climate fluctuations and human water use and management, including widely understood consumption of water resources.

The GRACE, a joint USA and German satellite mission, launched in 2002, consists of two satellites on identical Low Earth Orbit following each other by approximately $220 \mathrm{~km}$ (Tapley et al., 2004). In order to deliver accurate gravity field models with high spatial resolution, the inter-satellite range is observed with less than $1 \mu \mathrm{m} / \mathrm{s}$ accuracy, which requires a precise orbit determination at the level of a few $\mathrm{cm}$ (Papanikolaou and Tsoulis, 2016). The primary objective of the mission is to monitor gravity field variations (Tapley et al., 2004). The gravity field models are currently available with monthly resolution from dedicated processing centres: GFZ (GeoforschungsZentrum Potsdam), CSR (Center for Space Research at University of Texas, Austin) and JPL (Jet Propulsion Laboratory) (Bettadpur, 2012; Sakumura et al., 2014). Using these gravity field models, TWS variations can be derived (Kusche et al., 2009; Yi and Wen, 2016). Characteristics of TWS variations are then analysed by estimation of annual, 
semi-annual period terms, linear trend term, an acceleration term and a bias (Kiss and Földváry, 2016). Note already at this point that hydrological processes can be determined from GRACE only with limitations, since GRACE TWS estimates are horizontally averaged and vertically integrated (Kiss and Földváry, 2017).

The goal of GLDAS is to provide estimates for land hydrosphere parameters, such as water storage, energy storage and fluxes (Rodell et al., 2004; Kumar et al., 2006). Within GLDAS, four models with hydrologic information (Land Surface Models - LSMs) are available, namely Variable Infiltration Capacity Model (VIC), National Centers for Environmental Prediction/Oregon State University/Air Force/Hydrologic Research Lab Model (NOAH), Mosaic Model and Common Land Surface Model (CLM). Basic description of GLDAS variables can be found in

https://hydro1.gesdisc.eosdis.nasa.gov/ dods/GLDAS NOAH10 M.2.0.info.

The research was conducted for the region of the Sudety Mountains (Fig. 1), which extend for about $300 \mathrm{~km}$ along the Polish border with the Czech Republic and Germany, in the south-western Poland, from the vicinity of Gate Luzycka to the Moravian Gate. The highest peak of Sudety is Sniezka (1 $603 \mathrm{~m}$ a.s.l., in the Western Sudety). Average annual precipitation in Sudety ranges from $650-700 \mathrm{~mm}$, but in the highest mountain zones, it reaches to approximately $1200 \mathrm{~mm}$ per year (Olichwer and Tarka, 2005).

The region is characterized by a very dense network of rivers. Main rivers of the region are Oder, Elbe and Morava (Danube left tributary). The mountains are the watershed between the basins of the Oder, Elbe and Danube rivers. Almost all the area is located in the basin of Oder and thus belongs to the Baltic Sea catchment area. Only a small part belongs to the Elbe River basin (catchment area of the North Sea) and the Danube (Black Sea basin). According to Tarka (1997) in the region of Sudety there was not observed statistically significant changes in groundwater level during twenty-year period of 19611980. Further research was conducted by Buczyński et al. (2005) based on direct wells measurements. There is no consensus among the authors regarding the impact of climate change on groundwater level in the Sudety area (Buczyński et al., 2005; Olichwer and Tarka, 2005).

This terrain is much diversified in terms of hydrology, detailed research usually concern small areas (Buczyński and Staśko, 2015; Olichwer and Tarka, 2005). Analyses performed in this paper cover big surface, six one by one degree cells were admitted for the study, and it is over $45 \mathrm{k}$ square kilometres. That is why the results are very general, they refer to mean values of each cell.

\section{DATA AND METHODOLOGY}

The analysis included six 1 by 1 degree cells, which were chosen to cover the Sudety area (Fig. 1). The water balance could be computed for the period of available GLDAS data, which is January 1979 till now. The groundwater level (see eq. 2), as it contains GRACE data, was computed for the period of available GRACE data, trimmed to full hydrological years, it gave the period of November 2002 to October 2015, so analysis of water balance was also adjusted to this time.

Basic equation for total water storage, TWS, reads as (Xiao et al., 2015):

$T W S=S M+S W E+G W L$

where $S M, S W E, G W L$ are soil moisture, snow water equivalent and groundwater level, respectively. Total soil moisture was obtained by summing all four layers from the NOAH model. Generally, these values are expressed in units of distance, since they can be considered as equivalent water column height. TWS data were acquired from GRACE monthly solutions provided by NASA Jet Propulsion Laboratory (JPL), using the RL05 Level-2 data set, reprocessed at JPL in Nov. 2014 (RL05.1) (Swenson, 2012). The ftp address for the data acquisition is as follows: ftp://podaacftp.jpl.nasa.gov/allData/tellus/L3/land_mass/RL05/ascii/.

The data were computed at JPL using the Gaussian filter with radius of $300 \mathrm{~km}$ and maximum degree of 60. Also, the time mean of TWS values for the years 2004-2009 were removed. The signalleakage from surrounding areas was applied according to the file CLM4.LEAKAGE_ERROR.DS.G300KM.RL05. DSTvSCS1401.txt available at the above ftp address.

This paper examines the groundwater level variations, which can be derived from equation (1) by differentiation with respect to time, and the result is (in meters per second):

$$
\Delta G W L=\Delta T W S-\Delta S W E-\Delta S M
$$

where the abbreviations are the same as in (1), and the symbol $\Delta$ indicates time differences (as an approximation of time derivatives). The water balance describes the mass variations of the water cycle. It is calculated, also in meters per second, according to (Voss et al., 2013):

$$
\Delta S=S F+R F-E V-Q S-Q B
$$

where $\Delta S$ is the water balance, $S F$ is snowfall rate, $R F$ is rainfall rate, $E V$ is the evapotranspiration, $Q S$ is surface run-off and $Q B$ means subsurface runoff, conceptually including groundwater run-off. But it was shown in (Voss et al., 2013) that the groundwater changes are not taken into consideration properly in land data assimilation models and that TWS berger senses groundwater level variations. This is also the case with our data, see equation 4 . The sum of rain and snow falls is known as 
Table 1 Water balance and its components; data span: November 2002 - October 2015. Names of coefficients see eq. 5 .

\begin{tabular}{|c|c|c|c|c|c|c|c|}
\hline Parameter & coefficient & Cell 1 & Cell 2 & Cell 3 & Cell 4 & Cell 5 & Cell 6 \\
\hline \multirow{4}{*}{ Precipitation } & $\mathrm{a}_{0}[\mathrm{~m} / \mathrm{s}]$ & $1.68 \mathrm{e}-08$ & $2.01 \mathrm{e}-08$ & $2.21 \mathrm{e}-08$ & $1.94 \mathrm{e}-08$ & $1.95 \mathrm{e}-08$ & $1.93 \mathrm{e}-08$ \\
\hline & $\mathrm{a}_{\mathrm{t}}\left[\mathrm{m} / \mathrm{s}^{2}\right]$ & $1.11 \mathrm{e}-17$ & $1.37 \mathrm{e}-17$ & $-6.04 e-18$ & $4.63 \mathrm{e}-19$ & $-2.33 e-18$ & $9.38 \mathrm{e}-19$ \\
\hline & & $-7.21 e-09$ & $-8.78 \mathrm{e}-09$ & $-8.13 e-09$ & $-8.64 \mathrm{e}-09$ & $-7.97 e-09$ & $-7.75 e-09$ \\
\hline & $a_{c}[\mathrm{~m} / \mathrm{s}]$ & $2.62 \mathrm{e}-10$ & $1.30 \mathrm{e}-10$ & $-6.67 \mathrm{e}-10$ & $-1.23 \mathrm{e}-09$ & $-9.64 \mathrm{e}-10$ & $-6.44 \mathrm{e}-10$ \\
\hline \multirow[t]{4}{*}{ Evapotranspiration } & $\mathrm{a}_{0}[\mathrm{~m} / \mathrm{s}]$ & $1.65 \mathrm{e}-08$ & $1.83 \mathrm{e}-08$ & $1.99 \mathrm{e}-08$ & $1.83 \mathrm{e}-08$ & $1.89 \mathrm{e}-08$ & $1.84 \mathrm{e}-08$ \\
\hline & $a_{t}[n$ & $5.96 \mathrm{e}-18$ & $3.60 \mathrm{e}-18$ & -3.88 & $1.46 \mathrm{e}-18$ & $-3.00 e-18$ & $3.70 \mathrm{e}-20$ \\
\hline & & $-1.92 \mathrm{e}-08$ & $-2.12 \mathrm{e}-08$ & $-2.10 \mathrm{e}-08$ & $-1.98 \mathrm{e}-08$ & $-2.02 \mathrm{e}-08$ & $-2.05 e-08$ \\
\hline & $a_{c}[n$ & $-8.46 \mathrm{e}$ & -7.4 & -7. & -09 & -8.2 & $-8.84 \mathrm{e}-09$ \\
\hline Run- & $5 \mathrm{~m}$ & 1.24 & 1.6 & 2.0 & -09 & e-09 & $1.32 \mathrm{e}-09$ \\
\hline & $a_{t}$ & $2.62 \mathrm{e}-18$ & $1.31 \mathrm{e}-17$ & $9.72 \mathrm{e}-19$ & -19 & $-6.72 e-19$ & $4.36 \mathrm{e}-19$ \\
\hline & $\mathrm{a}_{\mathrm{s}}[\mathrm{m} / \mathrm{s}]$ & $5.45 \mathrm{e}-10$ & $2.14 \mathrm{e}-09$ & $4.92 \mathrm{e}-10$ & -10 & $-4.89 e-13$ & $-2.08 \mathrm{e}-10$ \\
\hline & $a_{c}$ & $-9.89 e-10$ & -2.43 & -2.1 & $-9.01 e-10$ & $-6.75 e-10$ & $-9.35 e-10$ \\
\hline Water & $\mathrm{A}[\mathrm{m} / \mathrm{s}]$ & $-8.80 \mathrm{e}-10$ & $1.85 \mathrm{e}-10$ & $2.44 \mathrm{e}-10$ & $8.34 \mathrm{e}-11$ & $-6.74 e-10$ & $-4.19 \mathrm{e}-10$ \\
\hline Balance & $a_{t}\left[\mathrm{~m} / \mathrm{s}^{2}\right]$ & $2.52 \mathrm{e}-18$ & $-2.95 e-18$ & $-3.14 \mathrm{e}-18$ & $-1.92 \mathrm{e}-18$ & $1.34 \mathrm{e}-18$ & $4.66 \mathrm{e}-19$ \\
\hline \multirow{2}{*}{ (eq. 3) } & $\mathrm{a}_{\mathrm{s}}[\mathrm{m} / \mathrm{s}]$ & $1.14 \mathrm{e}-08$ & $1.03 \mathrm{e}-08$ & $1.24 \mathrm{e}-08$ & $1.15 \mathrm{e}-08$ & $1.23 \mathrm{e}-08$ & $1.29 \mathrm{e}-08$ \\
\hline & $u_{c} L$ & $9.72 \epsilon$ & 9.96 & 8.5 & $8.54 \mathrm{e}-09$ & $7.98 \mathrm{e}-09$ & $9.14 \mathrm{e}-09$ \\
\hline$\Delta \mathbf{h ~ |}$ & - & -0.149 & -0.169 & -0.161 & -0.125 & -0.163 & -0.132 \\
\hline$\overline{\mathbf{A h}}[\mathrm{mm} / \mathrm{y}]$ & - & -11 & -13 & -12 & -10 & -12 & -10 \\
\hline
\end{tabular}

precipitation. All the quantities occurring in righthand sides of equations 2 and 3, besides $T W S$, were taken from GLDAS NOAH model (Rui, 2016); downloaded from appropriate subdirectory of http://hydro1.sci.gsfc.nasa.gov/dods/). Units of all the quantities occurring in this equation are meters per seconds, referring to temporal changes of equivalent water column height.

As it is seen from eq. 3, the water balance is computed as the difference between the water flow-in (precipitation) and flow-out (evapotranspiration and surface plus subsurface run-off). But eq. 3 is an approximate form of water mass changes, and does not take into consideration all possible components of the water cycle. Most important term, not discovered properly, is groundwater level variations (Voss et al., 2013). They can be caused both by natural or anthropogenic (human water use and management) processes. Main processes which may change groundwater are infiltration via soil moisture (causing groundwater increase, $\mathrm{G}_{\text {in }}$ ) and groundwater flow out of the area (causing groundwater decrease, $G_{\text {out }}$ ). Nowadays, in some regions, groundwater consumption for irrigation and industrial purposes may also be significant. Resultant difference of groundwater level is designated as $\delta \mathrm{GWL}=\mathrm{G}_{\mathrm{in}}{ }^{-} \mathrm{G}_{\text {out }}$. When $\delta G W L$ is differentiated with respect to time, it provides $\triangle G W L$ in meters per seconds. Having $\triangle G W L$ from eq. 2, assuming that there are other factors, including model errors, which may have effect on water storage, and also accounting for unavoidable model errors, we can extend eq. 3 to:

$$
\begin{aligned}
\Delta S^{\prime} & =S F+R F-E V-Q S-Q B+ \\
& +\Delta G W L+\text { other_factors }
\end{aligned}
$$

To take into consideration an obvious seasonality in the data, all the time series were modelled according to:

$x_{t}=a_{0}+a_{t} t+a_{c} \cos \left(\omega_{0} t\right)+a_{s} \sin \left(\omega_{0} t\right)$

where coefficients $a_{0}, a_{t}, a_{s}, a_{c}$ were computed according to Least Squares adjustment, and $\omega_{0}$ is the annual frequency. To perform computations the linear regression model was used (Shumway and Stoffer, 2011).

Change of equivalent water height, resulting from $\Delta \mathrm{S}$ or $\Delta \mathrm{S}^{\prime}$ components included in eqs. 3 and 4 , may be computed as:

$$
\Delta h=a_{0} * \Delta t+a_{t} * \frac{\Delta t^{2}}{2}
$$

\section{VARIABILITY OF WATER BALANCE AND ITS COMPONENTS}

Basic characteristics of eq. 3 components for the studied six cells are given in Table 1 . To be consistent with the period of TWS availability, all the data were analysed for the period of available GRACE data, cut to hydrological year, i.e. November 2002 - October 2015. Results are given in Table 1.

There are data of different orders of magnitude in the Table 1 and other tables throughout the paper. However, they are all given because they have to be shown somehow, and also since they were used to compute change of equivalent water column height $\Delta \mathrm{h}$ (see equation 6).

Units of $\Delta \mathrm{S}$ are kg per square meters per seconds which, in case of water can be simplified to meters per second referring to the velocity of changes of equivalent water thickness. The results for the 6 
Table 2 Groundwater level and its components; data span: November 2002 - October 2015; all the values have been differenced over time according to eq. 2 .

\begin{tabular}{lccccccc}
\hline Parameter & coefficient & \multicolumn{1}{c}{ Cell 1 } & \multicolumn{1}{c}{ Cell 2 } & \multicolumn{1}{c}{ Cell 3 } & \multicolumn{1}{c}{ Cell 4 } & \multicolumn{1}{c}{ Cell 5 } & \multicolumn{1}{c}{ Cell 6 } \\
\hline \multirow{3}{*}{ Total Water } & $\mathrm{a}_{0}[\mathrm{~m} / \mathrm{s}]$ & $2.01 \mathrm{e}-11$ & $2.91 \mathrm{e}-11$ & $9.33 \mathrm{e}-12$ & $1.09 \mathrm{e}-11$ & $-2.87 \mathrm{e}-12$ & $1.12 \mathrm{e}-11$ \\
Storage TWS & $\mathrm{a}_{\mathrm{t}}\left[\mathrm{m} / \mathrm{s}^{2}\right]$ & $-1.29 \mathrm{e}-19$ & $-2.46 \mathrm{e}-19$ & $-1.56 \mathrm{e}-19$ & $-1.24 \mathrm{e}-19$ & $-7.59 \mathrm{e}-20$ & $-1.38 \mathrm{e}-19$ \\
& $\mathrm{a}_{\mathrm{s}}[\mathrm{m} / \mathrm{s}]$ & $-1.47 \mathrm{e}-10$ & $-4.63 \mathrm{e}-11$ & $-7.75 \mathrm{e}-11$ & $-1.45 \mathrm{e}-10$ & $-8.91 \mathrm{e}-11$ & $-1.38 \mathrm{e}-10$ \\
& $\mathrm{a}_{\mathrm{c}}[\mathrm{m} / \mathrm{s}]$ & $4.91 \mathrm{e}-10$ & $1.42 \mathrm{e}-09$ & $1.21 \mathrm{e}-09$ & $7.04 \mathrm{e}-10$ & $7.77 \mathrm{e}-10$ & $7.55 \mathrm{e}-10$ \\
\hline Soil Moisture & $\mathrm{a}_{0}[\mathrm{~m} / \mathrm{s}]$ & $-1.06 \mathrm{e}-09$ & $-7.50 \mathrm{e}-12$ & $1.20 \mathrm{e}-10$ & $5.53 \mathrm{e}-11$ & $-8.16 \mathrm{e}-10$ & $-5.02 \mathrm{e}-10$ \\
& $\mathrm{a}_{\mathrm{t}}\left[\mathrm{m} / \mathrm{s}^{2}\right]$ & $3.29 \mathrm{e}-18$ & $-2.04 \mathrm{e}-18$ & $-2.55 \mathrm{e}-18$ & $-1.74 \mathrm{e}-18$ & $1.86 \mathrm{e}-18$ & $7.98 \mathrm{e}-19$ \\
& $\mathrm{a}_{\mathrm{s}}[\mathrm{m} / \mathrm{s}]$ & $8.60 \mathrm{e}-09$ & $7.29 \mathrm{e}-09$ & $9.74 \mathrm{e}-09$ & $8.88 \mathrm{e}-09$ & $9.66 \mathrm{e}-09$ & $1.00 \mathrm{e}-08$ \\
& $\mathrm{a}_{\mathrm{c}}[\mathrm{m} / \mathrm{s}]$ & $1.17 \mathrm{e}-08$ & $1.06 \mathrm{e}-08$ & $9.94 \mathrm{e}-09$ & $1.02 \mathrm{e}-08$ & $9.80 \mathrm{e}-09$ & $1.12 \mathrm{e}-08$ \\
\hline Snow water & $\mathrm{a}_{0}[\mathrm{~m} / \mathrm{s}]$ & $2.01 \mathrm{e}-11$ & $2.91 \mathrm{e}-11$ & $9.33 \mathrm{e}-12$ & $1.09 \mathrm{e}-11$ & $-2.87 \mathrm{e}-12$ & $1.12 \mathrm{e}-11$ \\
equivalence & $\mathrm{a}_{\mathrm{t}}\left[\mathrm{m} / \mathrm{s}^{2}\right]$ & $-1.29 \mathrm{e}-19$ & $-2.46 \mathrm{e}-19$ & $-1.56 \mathrm{e}-19$ & $-1.24 \mathrm{e}-19$ & $-7.59 \mathrm{e}-20$ & $-1.38 \mathrm{e}-19$ \\
& $\mathrm{a}_{\mathrm{s}}[\mathrm{m} / \mathrm{s}]$ & $-1.47 \mathrm{e}-10$ & $-4.63 \mathrm{e}-11$ & $-7.75 \mathrm{e}-11$ & $-1.45 \mathrm{e}-10$ & $-8.91 \mathrm{e}-11$ & $-1.38 \mathrm{e}-10$ \\
& $\mathrm{a}_{\mathrm{c}}[\mathrm{m} / \mathrm{s}]$ & $4.91 \mathrm{e}-10$ & $1.42 \mathrm{e}-09$ & $1.21 \mathrm{e}-09$ & $7.04 \mathrm{e}-10$ & $7.77 \mathrm{e}-10$ & $7.55 \mathrm{e}-10$ \\
\hline Ground water & $\mathrm{a}_{0}[\mathrm{~m} / \mathrm{s}]$ & $4.70 \mathrm{e}-10$ & $-5.95 \mathrm{e}-10$ & $-6.93 \mathrm{e}-10$ & $-6.16 \mathrm{e}-10$ & $1.80 \mathrm{e}-10$ & $-1.30 \mathrm{e}-10$ \\
level & $\mathrm{a}_{\mathrm{t}}\left[\mathrm{m} / \mathrm{s}^{2}\right]$ & $-1.73 \mathrm{e}-18$ & $3.63 \mathrm{e}-18$ & $3.94 \mathrm{e}-18$ & $2.98 \mathrm{e}-18$ & $-2.03 \mathrm{e}-19$ & $8.17 \mathrm{e}-19$ \\
variation & $\mathrm{a}_{\mathrm{s}}[\mathrm{m} / \mathrm{s}]$ & $-6.74 \mathrm{e}-10$ & $6.80 \mathrm{e}-10$ & $-1.60 \mathrm{e}-09$ & $-5.15 \mathrm{e}-10$ & $-8.96 \mathrm{e}-10$ & $-1.16 \mathrm{e}-09$ \\
(eq. 2) & $\mathrm{a}_{\mathrm{c}}[\mathrm{m} / \mathrm{s}]$ & $-6.09 \mathrm{e}-09$ & $-6.09 \mathrm{e}-09$ & $-5.29 \mathrm{e}-09$ & $-5.17 \mathrm{e}-09$ & $-4.48 \mathrm{e}-09$ & $-5.98 \mathrm{e}-09$ \\
\hline $\boldsymbol{\Delta h}[\mathbf{m}]$ & - & $\mathbf{0 . 0 4 8}$ & $\mathbf{0 . 0 5 7}$ & $\mathbf{0 . 0 4 3}$ & $\mathbf{- 0 . 0 0 5}$ & $\mathbf{0 . 0 5 6}$ & $\mathbf{0 . 0 1 4}$ \\
$\overline{\mathbf{A h}}[\mathbf{m m} / \mathbf{y}]$ & - & $\mathbf{3 . 6}$ & $\mathbf{4 . 4}$ & $\mathbf{3 . 3}$ & $\mathbf{- 0 . 4}$ & $\mathbf{4 . 3}$ & $\mathbf{1 . 1}$ \\
\hline
\end{tabular}

studied cells (Fig. 2) are very similar to each other. The values of $\Delta S$ generally do not sum to zero (Birylo et al., 2016), they generally lie between $-4 e^{-8} \div 4 e^{-8} \mathrm{~m} / \mathrm{s}$. These residuals are assigned to groundwater level variations, further processes not accounted for by the models, and model uncertainties. The water balance data, like other hydrological parameters, has a strong seasonal component. The seasonal decomposition performed according to equation 5 shows that the $a_{\mathrm{s}}$ coefficients are of the order of $1 \mathrm{e}^{-8}$ and the $\mathrm{a}_{\mathrm{c}}$ are slightly smaller (order of $\left.9 \mathrm{e}^{-9}\right) . \quad \Delta \mathrm{S}$ values have a small linear trend $\left(\mathrm{a}_{\mathrm{t}}\right.$ coefficient), which is contained between $-3.14 \mathrm{e}-18$ to $2.52 \mathrm{e}-18\left[\mathrm{~m} / \mathrm{s}^{2}\right]$, depending on the cell. Equivalent change of water column height $\Delta \mathrm{h}$ was calculated with equation 6 , using estimated values of $a_{0}$ and $a_{t}$. The original data, the coefficients $\mathrm{a}_{0}, \mathrm{a}_{s}, \mathrm{a}_{c}$ are in units of velocity, thus the trend $\left(a_{t}\right)$ is expressed in units of acceleration.

Values of equivalent $\Delta \mathrm{h}$ computed for the last epoch taken are given in the last column of Table 1. The time span $\Delta \mathrm{t}$ between the first and last epoch amounts to 13 years and it is taken in units of seconds in eq. 6 . It is seen that $\Delta \mathrm{h}$ computed is between -0.169 to $-0.125 \mathrm{~m}$ for the studied period, which gives from 10 to $-13 \mathrm{~mm} /$ year on average.

\section{GROUNDWATER LEVEL VARIATION AND ITS COMPONENTS}

Groundwater level, GWL was computed according to eq. 2, for the period November $2002-$ October 2015. The data originally given as input for this equation are expressed in meters (of total water thickness). We differentiated these values for two reasons: (1) TWS values are not full, but with time mean (2004.000 to 2009.999) removed, as it was mentioned in previous section, and (2) to be comparable with $\Delta \mathrm{S}$ values. The differentiation is performed in the simplest way: dividing the first time differences by $\Delta \mathrm{t}$ expressed in seconds. The differentiated values were again modelled using equation (5). The results obtained for the groundwater and its components changes is given in Table 2, and all successive resultant GWL values are presented in Figure 3. The total canopy water storage values obtained from GLDAS (NOAH) had not been taken into consideration, because they were significantly smaller than other components. For example, computed equivalent water column height changes, according to equation 6 , for the considered period caused by canopy storage changes, were less than $1 \mathrm{~mm}$ for all the cells.

Units of GWL and other GLDAS state components before differentiation are $\mathrm{kg}$ per square meter, which again is simplified to meters, TWS is in meters, too. After differentiation over time, the units agree with that of water balance. $\triangle G W L$ values range between $-2 e^{-8} \div 2 e^{-8} \mathrm{~m} / \mathrm{s}$, see Figure 3 , only in a few cases fall out this region. Looking through Table 2, it can be seen that the $\Delta \mathrm{GWL}$ have different linear trends: decreasing for cells 1 and 5, increasing for remaining cells. After integration performed according to eq. 6, the average changes of ground water levels between Nov. 2002 and Oct. 2015 are obtained. They are mostly positive (increase of water), and their values are on the level of 1 to $5.7 \mathrm{~cm}$, which means average increase of the groundwater level by about 1 to $4.4 \mathrm{~mm}$ per year. In case of cell 4 , the $\Delta \mathrm{h}$ is negative but very small, $-5 \mathrm{~mm}$ totally, which gives about $-0.4 \mathrm{~mm} /$ year. 
Table 3 Comparison of Total Water Storage from GRACE (differentiated) and water balance corrected for groundwater level variations; units are $[\mathrm{m} / \mathrm{s}]$ for $\mathrm{a}_{0}, \mathrm{a}_{\mathrm{s}}, \mathrm{a}_{\mathrm{c}},\left[\mathrm{m} / \mathrm{s}^{2}\right]$ for $\mathrm{a}_{\mathrm{t}}$ and $[\mathrm{m}]$ for $\Delta h$; data span November 2002 to October 2015

\begin{tabular}{lccccc|ccccc}
\hline Cell & \multicolumn{5}{c|}{$\Delta T W S$ from GRACE } & \multicolumn{5}{c}{ Water budget $\Delta S^{\prime}$} \\
\cline { 2 - 10 } No & $\mathrm{a}_{0}$ & $\mathrm{a}_{\mathrm{t}}$ & $\mathrm{a}_{\mathrm{s}}$ & $\mathrm{a}_{\mathrm{c}}$ & $\boldsymbol{\Delta h} \mathbf{h} \mathbf{m}]$ & $\mathrm{a}_{0}$ & $\mathrm{a}_{\mathrm{t}}$ & $\mathrm{a}_{\mathrm{s}}$ & $\mathrm{a}_{\mathrm{c}}$ & $\boldsymbol{\Delta h} \mathbf{m} \mathbf{m}]$ \\
\hline 1 & $2.01 \mathrm{e}-11$ & $-1.29 \mathrm{e}-19$ & $-1.47 \mathrm{e}-10$ & $4.91 \mathrm{e}-10$ & $\mathbf{- 0 . 1 1 7}$ & $-5.11 \mathrm{e}-10$ & $1.02 \mathrm{e}-18$ & $7.58 \mathrm{e}-09$ & $5.73 \mathrm{e}-09$ & $\mathbf{- 0 . 1 2 2}$ \\
2 & $2.91 \mathrm{e}-11$ & $-2.46 \mathrm{e}-19$ & $-4.63 \mathrm{e}-11$ & $1.42 \mathrm{e}-09$ & $\mathbf{- 0 . 1 2 2}$ & $-5.28 \mathrm{e}-10$ & $1.07 \mathrm{e}-18$ & $7.80 \mathrm{e}-09$ & $5.71 \mathrm{e}-09$ & $\mathbf{- 0 . 1 2 5}$ \\
3 & $9.32 \mathrm{e}-12$ & $-1.56 \mathrm{e}-19$ & $-7.75 \mathrm{e}-11$ & $1.20 \mathrm{e}-09$ & $\mathbf{- 0 . 1 2 7}$ & $-5.75 \mathrm{e}-10$ & $1.25 \mathrm{e}-18$ & $7.83 \mathrm{e}-09$ & $5.72 \mathrm{e}-09$ & $\mathbf{- 0 . 1 3 0}$ \\
4 & $1.09 \mathrm{e}-11$ & $-1.24 \mathrm{e}-19$ & $-1.45 \mathrm{e}-10$ & $7.04 \mathrm{e}-10$ & $\mathbf{- 0 . 1 3 1}$ & $-5.93 \mathrm{e}-10$ & $1.27 \mathrm{e}-18$ & $8.04 \mathrm{e}-09$ & $5.64 \mathrm{e}-09$ & $\mathbf{- 0 . 1 3 6}$ \\
5 & $-2.87 \mathrm{e}-12$ & $-7.59 \mathrm{e}-20$ & $-8.91 \mathrm{e}-11$ & $7.77 \mathrm{e}-10$ & $\mathbf{- 0 . 1 2 8}$ & $-5.89 \mathrm{e}-10$ & $1.39 \mathrm{e}-18$ & $8.55 \mathrm{e}-09$ & $5.94 \mathrm{e}-09$ & $\mathbf{- 0 . 1 2 4}$ \\
6 & $1.12 \mathrm{e}-11$ & $-1.38 \mathrm{e}-19$ & $-1.38 \mathrm{e}-10$ & $7.55 \mathrm{e}-10$ & $\mathbf{- 0 . 1 3 0}$ & $-5.97 \mathrm{e}-10$ & $1.40 \mathrm{e}-18$ & $8.62 \mathrm{e}-09$ & $5.72 \mathrm{e}-09$ & $\mathbf{- 0 . 1 2 7}$ \\
\hline
\end{tabular}

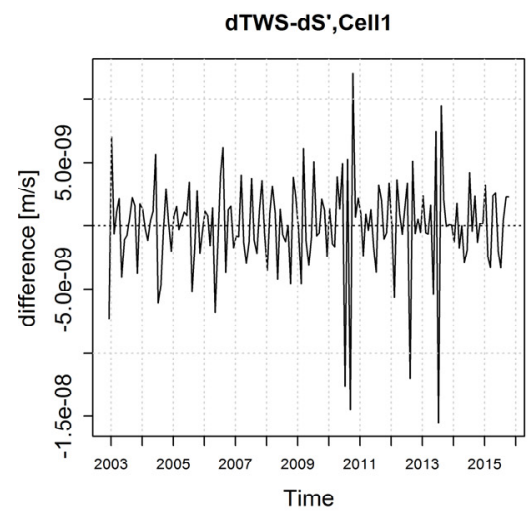

dTWS-dS',Cell4

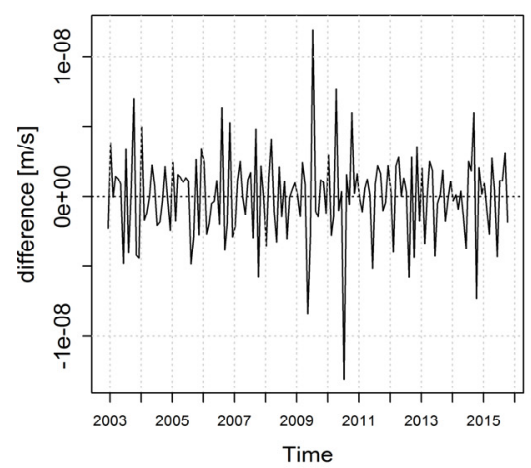

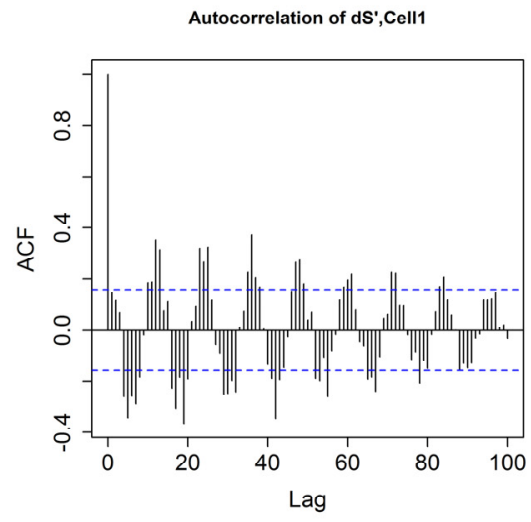

Autocorrelation of dS',Cell4

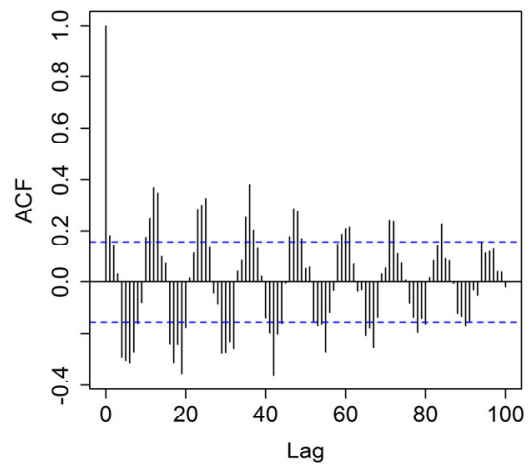

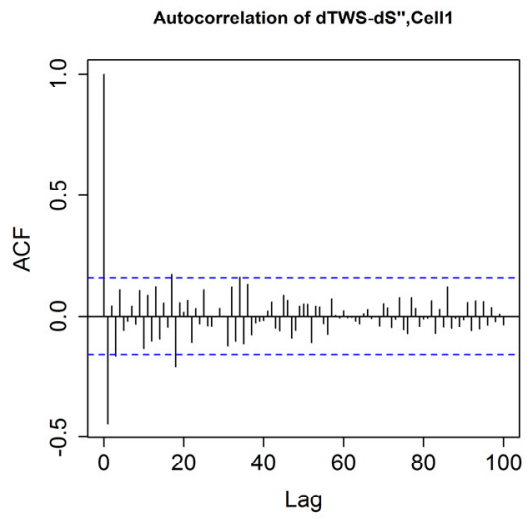

Autocorrelation of dTWS-dS',Cell4

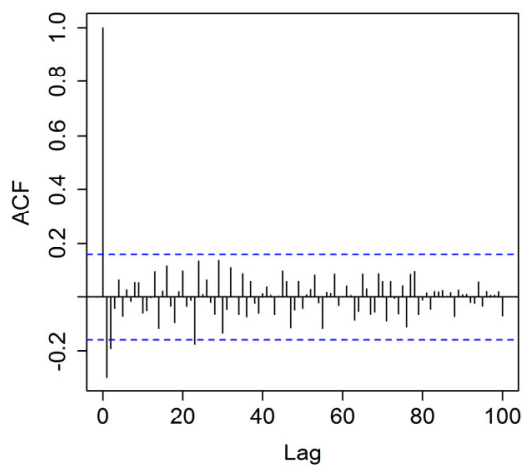

Fig. 5 Residuals of $\triangle S^{\prime}$ and $\triangle T W S$ (left column), autocorrelation functions of $\Delta S^{\prime}$ (middle column) and residuals $\left(\triangle S^{\prime}-\triangle T W S\right)$ - right column, for cells 1 (top row) and 4 (bottom row).

\section{DISCUSSION}

In order to distinguish the adequate form of water balance change (eq. 4) from the approximate one (eq. 3), the latter is noted by $\Delta S^{\prime}$. The computed value of $\Delta S^{\prime}$ can also be regarded as total water storage change, computed on the basis of GLDAS flux data corrected for groundwater level variations. In Table 3 bias, trend and equivalent water column height change computed for $\triangle T W S$ and $\triangle S^{\prime}$ are provided. These values refer to the period of 13 years, thus it may be assumed that $\Delta h$ for one year does not exceed $1 \mathrm{~cm}$. Values obtained for GRACE data are generally smaller. It can be seen that there is a good agreement between values of TWS obtained from GRACE and from GLDAS NOAH model. Also, it can be concluded that the variations during the analysed period were rather small.
Figure 4 shows both $\triangle T W S$ from GRACE and water balance $\Delta S^{\prime}$ for the six cells. There is a high correlation between the plotted values; correlation coefficients are over 0.9 for all the cells. Differences between $\Delta \mathrm{S}$ ' and $\Delta$ TWS bring information on "other factors" from eq. 4. These differences are now referred to as 'residuals'. Figure 5, left column, shows these residuals for two chosen cells ( 1 and 4 , see Figure 1); results obtained for the other cells are highly similar, therefore they have not been shown here. It can be seen that amplitudes of the residuals are relevantly smaller than that of $\Delta S^{\prime}$ (provided only for comparison), but there are also some outliers, which reaches (absolute) values of $2 * 10^{-8} \mathrm{~m} / \mathrm{s}$. In order to determine the spectral characteristics of $\Delta \mathrm{S}^{\prime}$ and the residuals, autocorrelation of these time series has been determined (middle and right figures of Figure 5). 
Based on the autocorrelations, there is an obvious seasonality of the signal detected on the $\Delta \mathrm{S}^{\prime}$ time series, see Figure 5, middle column. No such seasonality can be seen on the autocorrelation plot of the residuals, see Figure 5, right column. Thus, it can be stated that the main difference between $\Delta S$ ' and the residuals is the lack of seasonality, which would be of practical significance.

As it was mentioned, the non-balanced values of the $\triangle S^{\prime}-\triangle T W S$ residuals reflect the effect of other factors, not included in eq. 3. When they are integrated over time, from November 2002 to October 2015, it should give the change of the equivalent water column height caused by these factors. The obtained $\Delta h$ are included in the range of $-1.5 \mathrm{~cm}$ to $1.5 \mathrm{~cm}$. Since in our climate several hydrological parameters have significant seasonal frequency, and the "other factors" determined here do not show such behaviour, it is very likely that the main component of the "other factors" are uncertainties in the model values (Chen et al., 2016).

\section{CONCLUSIONS}

In the paper, groundwater level variations, water balance and other related hydrological quantities were computed and analysed for the area of the Sudety Mountains. Analyses refer to the period of November 2002 to October 2016.

It was shown that groundwater changes computed on the basis of GRACE total water storage and stable GLDAS data (soil moisture and snow water equivalence) are consistent with the water balance determined from flux GLDAS variables (precipitation, evaporation, surface and subsurface run-off). Not balanced residuals were found to be generally random, which may not be judged whether non-periodic water balance changes due to present day climate change or model errors. The computations of groundwater were performed on differentiated data. It is known that numerical differentiation may introduce relevant errors, particularly in the case of the simplest numerical differentiation, as it was performed in this study, which may enlarge the errors by a factor of $\sqrt{2}$ (Földváry, 2007). Nevertheless, a satisfactory agreement between water balance together with groundwater changes included, and total water storage from GRACE was achieved.

Taking advantage of this result, it would be possible to estimate groundwater level changes also for times when the GRACE data were not available, like the period 1979-2002.

On the terrain of the six studied cells, variations of TWS computed from GRACE and GLDAS NOAH model are equivalent to water heights changes of about $-12 \mathrm{~cm}$ during 13 years, i.e. about $1 \mathrm{~cm}$ per year (see Table 3). In the same period however, changes of groundwater were about twice smaller in their absolute values and mostly positive (see Table 2). Thus TWS, both from GRACE and GLDAS, decreases and GWL slightly increases (in 5 per 6 cells). It seems the change of TWS at almost stable GWL must result from lowering soil moisture and snow water equivalence. In all the considerations we should keep in mind that these variations refer to average values of whole one degree cells (approximately 60 by $100 \mathrm{~km}$ at latitude of $50^{\circ}$ ).

\section{ACKNOWLEDGEMENTS}

The work was supported by the National Science Centre, Poland, the agreement number UMO-2015/17/B/ST10/03927 from 16th March 2016.

The GLDAS data used in this study were acquired as part of the NASA's Earth-Sun System Division and archived and distributed by the Goddard Earth Sciences (GES) Data and Information Services Center (DISC) Distributed Active Archive Center (DAAC).

\section{REFERENCES}

Barlik, M., Pachuta, A. and Olszak, T.: 2007, Monitoring of long-term absolute gravity changes in Polish territory. XX Jesienna Szkoła Geodezji, Polanica, Poland, (in Polish).

Bettadpur, S.: 2012, Level-2 gravity field product user handbook, GRACE 327-734 (CSR-GR-03-01). Rev 3.0, May 29, 2012, University of Texas, Centre of Space Research.

Birylo, M., Rzepecka, Z. and Nastula, J.: 2016, Evaluation of the global land data assimilation system (GLDAS) data products essential for determination groundwater in Poland. 16th International Multidisciplinary Scientific Conference SGEM 2016, SGEM2016 Conference Proceedings, Book 3, 1, 313-320. DOI: $10.5593 /$ SGEM2016/B31/S12.041

Buczyński, S., Staśko, S. and Tarka, R.: 2005, Dynamics of the hydraulic heads on the Sudety Mountains Foreland - the Zebrzydów station. Współczesne Problemy Hydrogeologii, XII, Toruń, 71-76, (in Polish).

Buczyński, S. and Staśko, S.: 2015, Groundwater flow systems in the Sudeten Mountains: A Study of the Kamienczyk Catchment Area. Episodes, 39, 3. DOI:10.18814/epiiugs/2016/v39i3/99769

Chen, J., Famiglietti, J.S., Scanlon, B.R and Rodell, M.: 2016, Groundwater storage changes: Present status from GRACE observations. Surv. Geophys., 37, 2, 397-417. DOI 10.1007/s10712-015-9332-4

Famiglietti, J.S. and Rodell, M.: 2013, Water in the balance. Science, 340, 6138, 1300-1301. DOI: $10.1126 /$ science. 1236460

Földváry, L.: 2007, Analysis of numerical differentiation methods applied for determination of kinematic velocities for LEOs. Periodica Polytechnica, Civil Engineering, 51, 1, 17-24.

Kiss, A. and Földváry, L.: 2016, Uncertainty of GRACEborne long periodic and secular ice mass variations in Antarctica. Acta Geod. Geophys. DOI: 10.1007/s40328-016-0185-1

Kiss, A. and Földváry, L.: 2017, Comparison of seasonal hydrologic variations in the La Plata basin from GRACE monthly solutions with in situ gauge water level data. Acta Geodyn. Geomater., 14, No. 2 (186), 145-152. DOI: 10.13168/AGG.2016.0035 
Kumar, S. V., Peters-Lidard, C.D., Tian, Y., Houserb, P.R., Geigerb, J., Oldenb, S., Lightyb, L., Eastmana, J.L., Dotyc, B., Dirmeyerc, P., Adamsc, J., Mitchelld, K., Woode, E.F. and Sheffielde, J.: 2006, Land information system: An interoperable framework for high resolution land surface modelling. Environ. Model. Softw., 21, 10, 1402-1415. DOI:10.1016/j.envsoft.2005.07.004

Kusche, J., Schmidt, R., Petrovic, S. and Rietbroek, R.: 2009, Decorrelated GRACE time-variable gravity solutions by GFZ, and their validation using a hydrological model. Journal of Geodesy, 83, 10, 903913. DOI: $10.1007 / \mathrm{s} 00190-009-0308-3$

National Water Management, Annex 1 to the Draft of National Water Policy 2030, 2010, (in Polish).

Olichwer, T. and Tarka, R.: 2005, Are Sudety Mts. waterless area on Klodzko land example. Współczesne Problemy Hydrogeologii, XII, Toruń, Poland, 71-76, (in Polish).

Papanikolaou, T.D. and Tsoulis, D.: 2016, Assessment of numerical integration methods in the context of estimating the motion of low Earth orbiters and inter-satellite observation analysis. Acta Geod. Geophys., 51, 4, 619-641. DOI: $10.1007 / \mathrm{s} 40328-016-0159-3$

Rodell, M., Houser, P. R., Jambor, U., Gottschalck, J., Mitchell, K., Meng, C.J., Arsenault, K., Cosgrove, B., Radakovich, J., Bosilovich, M., Entin, J. K., Walker, J. P., Lohmann, D. and Toll, D.: 2004, The global land data assimilation system. B. Am. Meteorol. Soc., 85, 3, 381-394. DOI: 10.1175/BAMS-85-3-381

Rui, H.: 2016, Read me document for Global Land Data Assimilation System V. 1 (GLDAS-1) Products.

Sakumura, C., Bettadpur, S. and Bruinsma, S.: 2014, Ensemble prediction and intercomparison analysis of GRACE time-variable gravity field models. Geophys. Res. Lett., 41, 5, 1389-1397. DOI: 10.1002/2013GL058632

Scanlon, B.R., Keese, K.E., Flint, A.L., Flint, L.E., Gaye, C.B., Edmunds, W.M. and Simmers, I.: 2006, Global synthesis of groundwater recharge in semiarid and arid region. Hydrol. Process., 20, 15, 3335-3370.

DOI: $10.1002 /$ hyp. 6335
Shumway. R.H. and Stoffer, D.S.: 2011, Time Series Analysis and Its Applications. Springer New York Dordrecht Heidelberg London.

Swenson, S.C.: 2012, GRACE monthly land water mass grids NETCDF release 5.0. PODAAC-TELNDNC005. DOI: 10.5067/TELND-NC005

Tapley, B.D., Bettadpur, S., Watkins, M. and Reigber, C.: 2004, The gravity recovery and climate experiment: Mission overview and early results. Geophys. Res. Lett., 31, 9, L09607. DOI: 10.1029/2004GL019920

Tarka, R.: 1997, Changes of groundwater level basing on chosen examples from Sudety and their foreland area against precipitation conditions. Współczesne Problemy Hydrogeologii, VIII, Poznań, 393-396, (in Polish).

Voss, K.A., Famiglietti, J.S., Lo, M., Linage, C., Rodell, M. and Swenson, S.C.: 2013, Groundwater depletion in the Middle East from GRACE with implications for transboundary water management in the TigrisEuphrates-Western Iran region. Water Resour. Res., 49, 2, 904-914. DOI: 10.1002/wrcr.20078

Xiao, R., He, X., Zhang, Y., Ferreira, V.G. and Chang, L.: 2015, Monitoring groundwater variations from satellite gravimetry and hydrological models: A comparison with in-situ measurements in the MidAtlantic Region of the United States. Remote Sens., 7, 1, 686-703. DOI: $10.3390 /$ rs 70100686

Yi, H. and Wen, L.: 2016, Satellite gravity measurement monitoring terrestrial water storage change and drought in the continental United States. Sci. Rep. 6, 19909. DOI: 10.1038/srep19909

Zektser, I.S. and Lorne, G.F. (Eds.): 2004, Groundwater resources of the world and their use. IHP-VI, Series on Groundwater No. 6, UNESCO, Paris, France. 


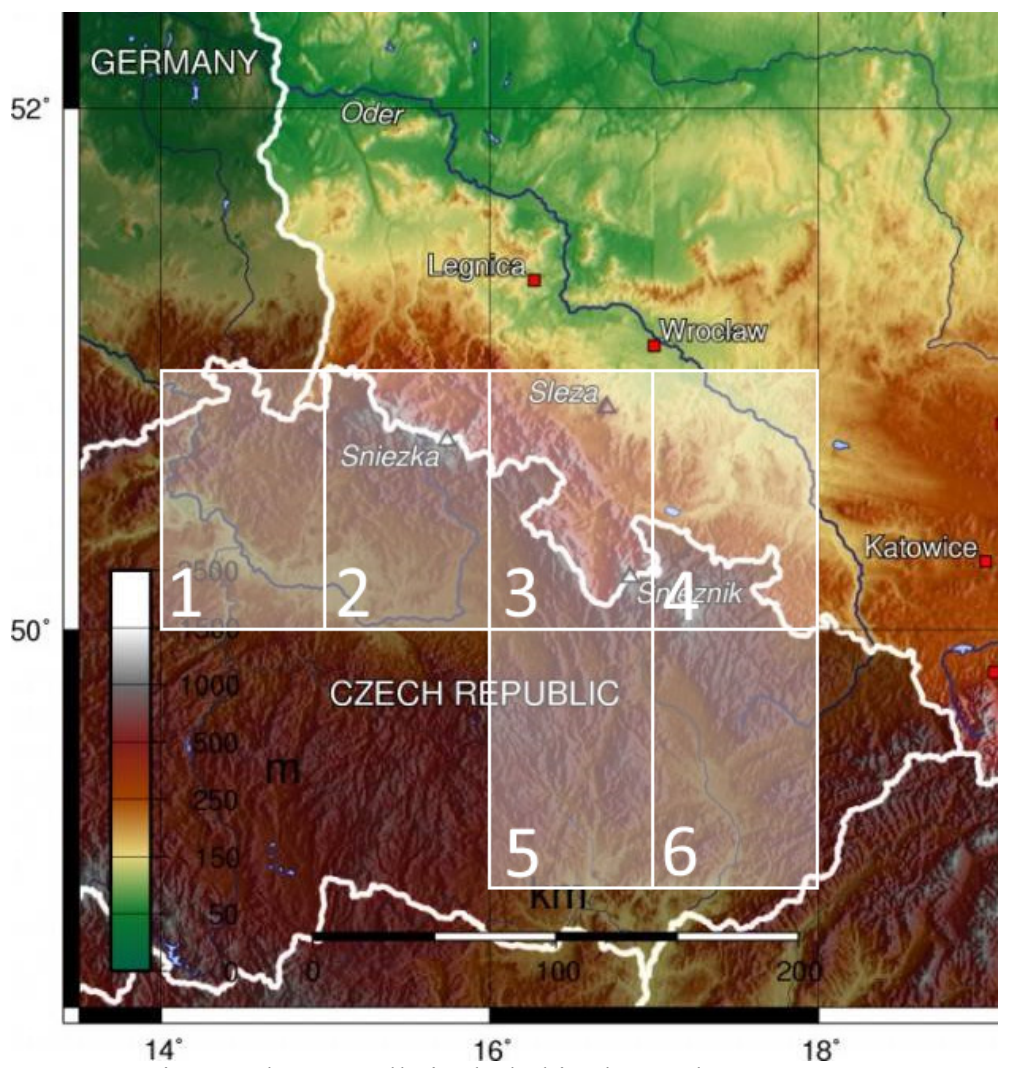

Fig. 1 Six one degree cells included in the study.

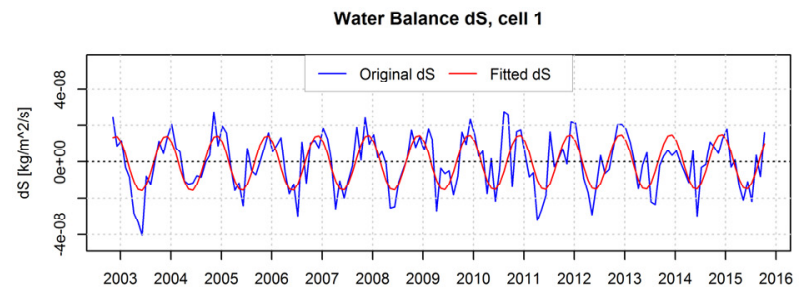

Time

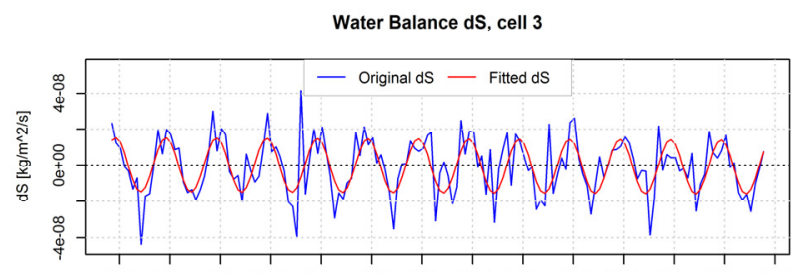

$\begin{array}{llllllllllllll}2003 & 2004 & 2005 & 2006 & 2007 & 2008 & 2009 & 2010 & 2011 & 2012 & 2013 & 2014 & 2015 & 2016\end{array}$

Time

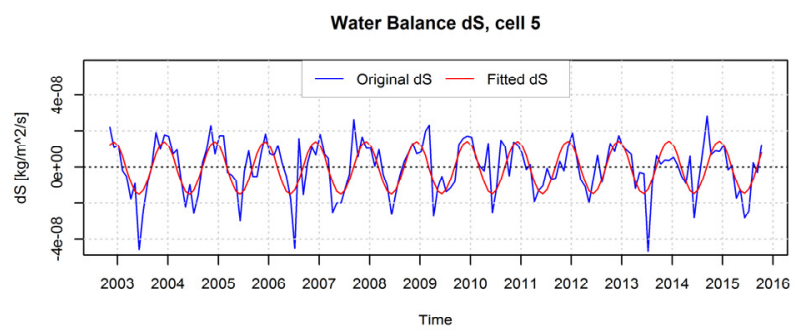

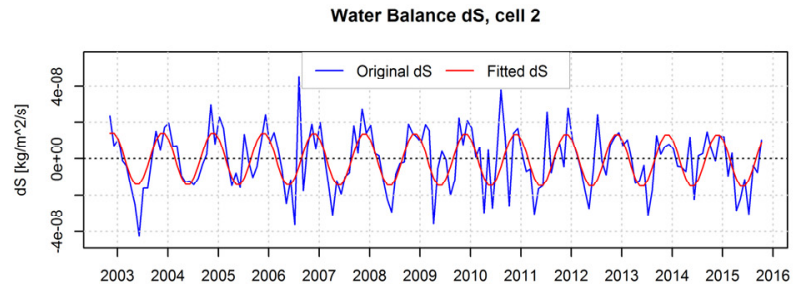

Time

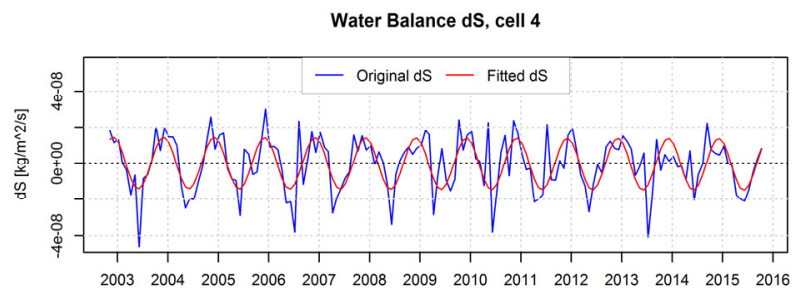

Time

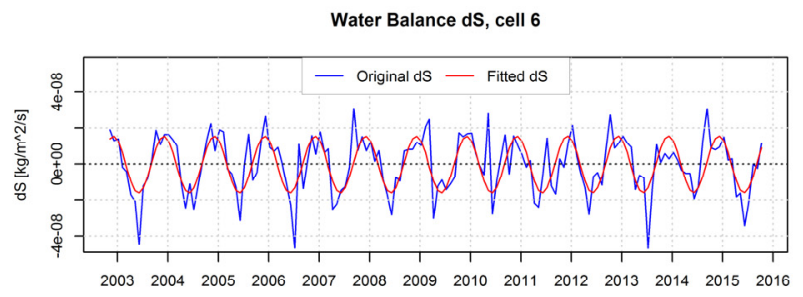

TIme

Fig. 2 Water balance ( $\Delta \mathrm{S})$ computed according to eq. 3 and its annual component, according to eq. 5. 


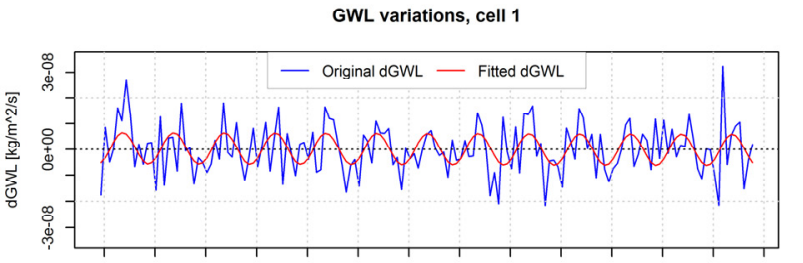

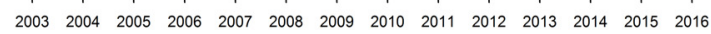
Time

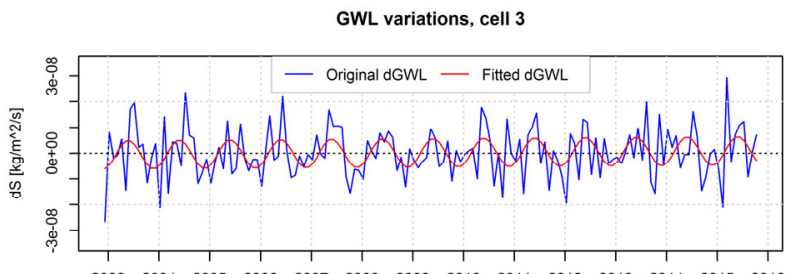

$\begin{array}{llllllllllllll}2003 & 2004 & 2005 & 2006 & 2007 & 2008 & 2009 & 2010 & 2011 & 2012 & 2013 & 2014 & 2015 & 2016\end{array}$ Time

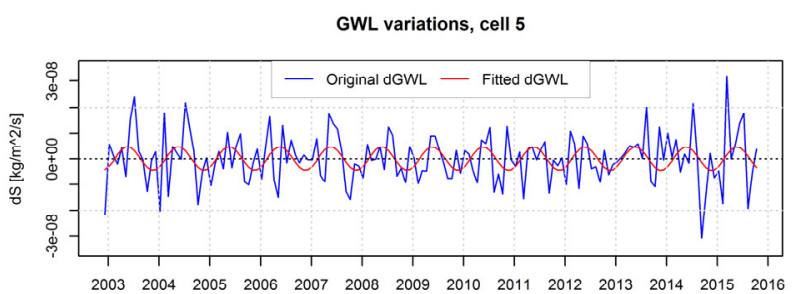

TIme

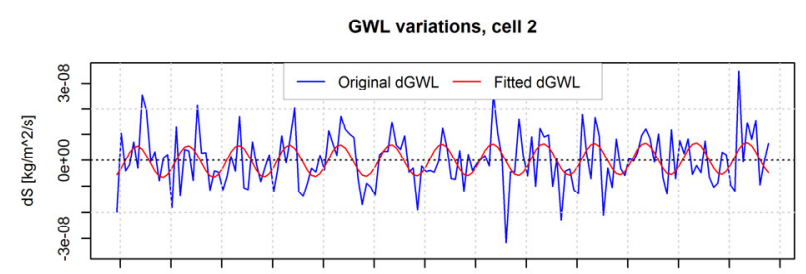

$200320042005200620072008 \quad 20092010 \quad 20112012 \quad 2013 \quad 2014 \quad 20152016$ Time

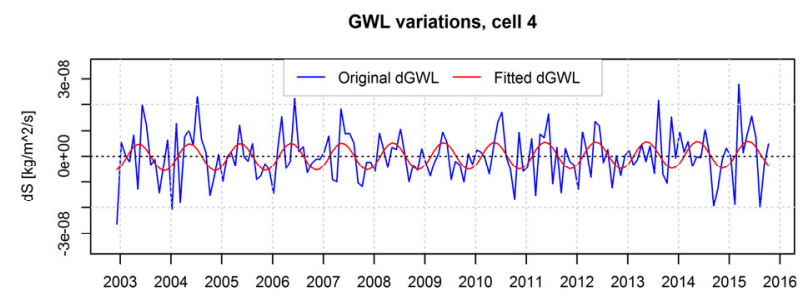
Time

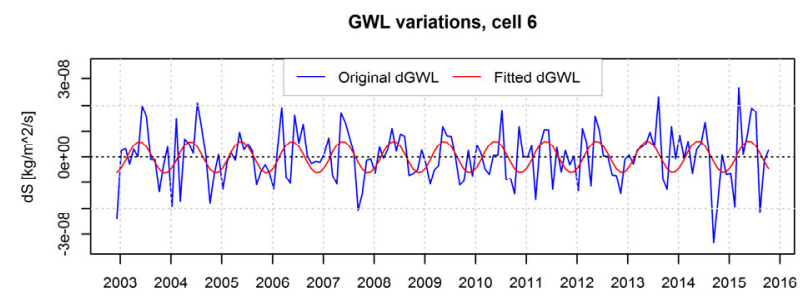

TIme

Fig. 3 Groundwater level variations computed according to eq. 3 and its annual component, according to eq. 5.
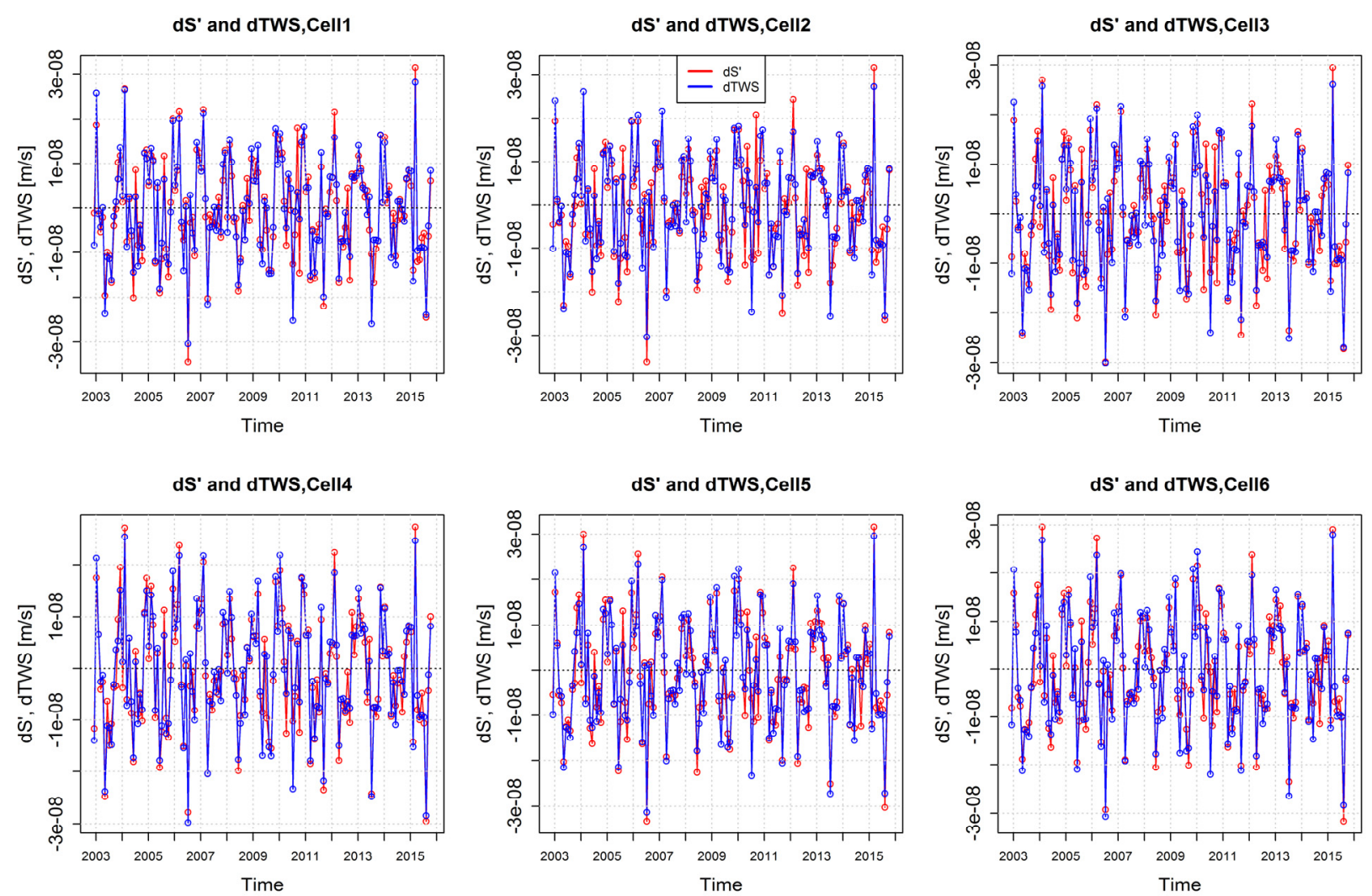

Fig. 4 Comparison of $\Delta S^{\prime}$ and $\Delta$ TWS for six tested cells. 